\title{
GAMBARAN KECEMASAN DAN KEPATUHAN REMAJA PUTRI TERHADAP KEBIASAAN BARU PADA MASA PANDEMI COVID-19 DI SURABAYA
}

\author{
${ }^{1)}$ Irma Maya Puspita, ${ }^{2)}$ Annisa' Wigati Rozifa, ${ }^{3)}$ A'im Matun Nadhiroh \\ Program Studi S1 Kebidanan, Fakultas Ilmu Kesehatan, Universitas Muhammadiyah Surabaya \\ J1. Raya Sutorejo No. 59, Dukuh Sutorejo, Kec. Mulyorejo, Kota Surabaya, Jawa timur, Indonesia \\ E-mail : ${ }^{1)}$ irmamayapuspita@gmail.com, ${ }^{2)}$ anisa.15wigati@gmail.com, ${ }^{3)}$ aimatunnadhiroh@ fik.um-surabaya.ac.id
}

\section{Kata Kunci: \\ Kecemasan, Remaja, COVID-19}

Keywords:

Anxiety, Adolescent, COVID-19

\section{Info Artikel}

Tanggal dikirim:27-9-2020

Tanggal direvisi:6-11-2020

Tanggal diterima: 23-1-2021 DOI Artikel:

10.36341/jomis.v5i1.1492

Creative Commons Attribution-

NonCommercial-ShareAlike 4.0 International License.

\begin{abstract}
ABSTRAK
Wabah pandemi COVID-19 tidak hanya mengancam kesehatan fisik, akan tetapi juga kesehatan psikologis masyarakat. Efek psikologis yang ditimbulkan dapat berdampak ringan hingga berat. Remaja memiliki usia yang masih labil, sehingga psikologisnya mudah terguncang, mengalami kecemasan berlebih dan ketakutan akan tertular virus. Cemas pada remaja merupakan reaksi yang wajar di masa pandemi COVID-19 ini. Namun, apabila berlangsung berlarut-larut, dapat menyebabkan gangguan psikologis. Penelitian ini menggunakan metode deskriptif dengan desain kuantitatif. Pengambilan sampel menggunakan teknik non-probability sampling yaitu purposive sampling, sehingga diperoleh sampel sebanyak 95 responden remaja putri. Penelitian ini bertujuan untuk mengungkap kecemasan dan kepatuhan remaja putri terhadap kebiasaan baru pada masa pandemi COVID-19 di Surabaya. Hasil penelitian ini menunjukkan bahwa responden terbanyak merupakan remaja dengan tingkat kecemasan ringan $(80 \%)$, diikuti remaja dengan tingkat kecemasan sedang $(8,4 \%)$, remaja dengan tingkat kecemasan berat $(10,5 \%)$. Kepatuhan remaja putri terhadap kebiasaan baru di masa New Normal diperoleh data selalu melakukan cuci tangan $(61,1 \%)$, selalu menggunakan masker $(86,3 \%)$, selalu menerapkan sosial distancing $(50,5 \%)$, dan tinggal di rumah sebanyak $(55,8 \%)$. Peran remaja dalam adaptasi kebiasaan baru sangat dibutuhkan untuk mencegah penularan COVID-19.
\end{abstract}

\begin{abstract}
The COVID-19 pandemic outbreak threatens not only physical health, but also the psychological health of society. Psychological effects have mild to severe impacts. Adolescents are still classified as unstable age, thus they are easily shaken psychologically, experiencing excess anxiety and fear of contracting the virus. Anxiety in adolescents is a natural reaction in this COVID-19 pandemic situation. However, if this situation lasts for a long time, it may cause psychological problems. This study used a descriptive methods with quantitative design. Population sampling used nonprobability sampling technique, i.e. purposive sampling, in order to obtain a sample of 95 female teenager respondents. This study aims to investigate the anxiety and compliant levels of the female teenager related to new habits during the COVID-19 pandemic in Surabaya. The results showed that the majority of respondents were adolescents with a mild $(80 \%)$, followed by moderate $(8.4 \%)$, and severe $(10.5 \%)$ level of anxiety. Compliant of the female teenagers to new habits during the New Normal period was achieved by washed our hands $(61.1 \%)$, always using masks $(86.3 \%)$, always applying social distancing $(50.5 \%)$, and staying at home $(55.8 \%)$. The role of adolescents in new habits is urgently needed to prevent transmission of COVID-19.
\end{abstract}

\section{PENDAHULUAN}

Wabah infeksi virus Corona telah menjangkit 216 negara, salah satunya adalah Indonesia. Jumlah pasien positif COVID-19 terus bertambah, dan angka kematian juga tergolong tinggi. Kasus COVID-19 pertama kali muncul di Indonesia pada awal Maret 2020. Kemenkes RI (2020), Corona Virus Disease
2019 ini merupakan penyakit yang disebabkan oleh keluarga besar corona virus yang dapat menyebabkan penyakit ringan sampai berat pada manusia dan hewan, seperti batuk atau pilek dan penyakit serius seperti MERS dan SARS yang dapat menyerang sistem pernapasan pada manusia. Berbagai langkah cepat telah dilakukan oleh pemerintah sebagai 
upaya mencegah penyebaran dan penularan virus ini, seperti himbauan untuk menjaga jarak, mencuci tangan dengan sabun, dan memakai masker, serta tinggal di rumah [1], [2].

Wabah COVID-19 ini mengganggu kesehatan fisik dan kesehatan psikologis setiap individu dan masyarakat [3], [4]. Efek psikologis yang ditimbulkan dapat berdampak ringan hingga berat. Gangguan psikis pada masa pandemi disebabkan karena beberapa faktor, yaitu ketakutan akan wabah, rasa terasingkan, rasa sedih jauh dari keluarga, rasa cemas terhadap kebutuhan hidup sehari-hari, serta adanya berita simpang siur [5]. Beredarnya informasi tentang penyakit ini, menyebabkan dampak positif dan negatif. Kita dianjurkan meng-update informasi agar selalu waspada. Namun, jika secara terus menerus, dapat menimbulkan efek tidak baik terhadap kesehatan mental, seperti memicu timbulnya stres, cemas, panik, dan rasa takut. Kondisi yang secara tiba-tiba datang menyebabkan masyarakat belum siap menghadapi secara fisik maupun psikis [6].

COVID-19 berhasil mengubah kebiasaan masyarakat sehari-hari. Saat ini, masyarakat mau tidak mau harus hidup dengan kebiasaan baru, yang berdampingan dengan COVID-19. Kebiasaan baru tersebut yaitu sering mencuci tangan pakai sabun, memakai masker, meningkatkan daya tahan tubuh dengan istirahat cukup, olahraga, dan makan makanan bergizi simbang, menjaga jarak dan menghindari kerumunan [7].

Masa remaja merupakan masa transisi dari anak-anak menuju dewasa dimana pada masa ini seseorang memiliki keadaan emosi yang labil dalam menghadapi kondisi yang tidak terduga, misalnya dalam masa pandemi ini mereka merasakan ketakutan dan kecemasan yang berlebihan terhadap penularan virus [8], [9]. Rasa cemas yang berlangsung secara terus menerus, dapat menimbulkan gangguan pada kesehatan fisik dan mental pada remaja [10]. Perempuan merupakan sosok yang dianggap lebih sensitif terhadap emosi dibandingkan dengan laki-laki. Jika terjadi sesuatu hal yang tidak wajar terhadap kondisi lingkungannya, maka perempuan akan lebih cepat peka dan merasakan ketidaknyamanan akan hal tersebut.
Oleh karena itu, peneliti menggunakan remaja putri sebagai populasi dalam penelitian ini.

Penambahan kasus yang terjadi setiap harinya menggambarkan bahwa kepatuhan terhadap kebiasaan baru masih belum optimal dilaksanakan oleh masyarakat. Remaja merupakan bagian dari masyarakat yang diharapkan dapat berpartisipasi menerapkan kebiasaan baru guna mengendalikan penyebaran virus corona. Penelitian ini bertujuan untuk mengungkap kecemasan dan kepatuhan remaja putri terhadap kebiasaan baru di masa pandemi COVID-19.

\section{TINJAUAN PUSTAKA}

Remaja merupakan proses dari anakanak menuju dewasa sehingga remaja perlu membentengi diri dari rasa cemas, stres dan panik yang berlebih dari informasi yang didapatkan baik secara mandiri, ataupun dari berbagai media lainnya [10]. Rasa takut dan cemas akan kondisi kesehatan diri sendiri dan keluarga dan susah tidur merupakan stres yang dapat timbul di masa pandemi COVID-19. Hal ini memperparah gangguan fisik dan psikologi seseorang yang memang memiliki riwayat penyakit kronis sebelumnya [11].

Penelitian yang terkait dengan penelitian ini adalah penelitian Fitria dan Ifdil (2020). Penelitian ini mengungkapkan tentang kondisi anxiety remaja pada masa pandemi COVID19. Berdasarkan hasil analisis penelitian tersebut, diketahui bahwa tingkat anxiety remaja di masa pandemi ini kategori rendah sebanyak $2,1 \%$, sedang $43,9 \%$ dan tinggi sebesar $54 \%$. Beberapa faktor penyebab anxiety di masa pandemi adalah minimalnya informasi akurat mengenai COVID-19 dan pemberitaan media yang berlebihan [12]

Penelitian terkait kepatuhan atas himbauan pemerintah pernah dilakukan oleh Sari, Sholihah, dan Atiqoh (2020). Penelitian tersebut membahas mengenai hubungan antara pengetahuan masyarakat dengan kepatuhan penggunaan masker sebagai upaya pencegahan penyakit COVID-19 di Ngronggah. Hasil penelitian dari 62 responden menunjukkan terdapat hubungan antara pengetahuan masyarakat terhadap kepatuhan penggunaan 
masker sebagai upaya pencegahan penyakit COVID-19 di Ngronggah [13].

Penelitian lain terkait kepatuhan perilaku physical distancing dilakukan oleh Syadidurrahmah, dkk (2020). Penelitian ini membahas perilaku Physical Distancing Mahasiswa UIN Syarif Hidayatullah Jakarta pada Masa Pandemi COVID-19. Hasil penelitian menunjukkan perilaku physical distancing yang baik dilakukan oleh 55,9\% mahasiswa dengan analisis multivariat jenis kelamin perempuan [14].

Berdasarkan penelitian yang relevan di atas, dapat disimpulkan bahwa remaja putri merupakan bagian dari masyarakat yang mengalami kecemasan dan mereka adalah kelompok usia yang berpartisipasi dalam menerapkan kebiasaan baru pada masa pandemi COVID-19.

\section{METODE}

Penelitian ini menggunakan metode deskritptif dengan desain kuantitatif. Penelitian dilakukan pada bulan Maret - Juni 2020. Populasi pada penelitian ini adalah remaja putri yang berdomisili di Surabaya. Kriteria inklusi pada penelitian ini yaitu berjenis kelamin perempuan dan berusia $11-20$ tahun, bersedia menjadi responden.

Teknik pengambilan sampel dalam penelitian ini menggunakan teknik non probability sampling yaitu purposive sampling, sehingga diperoleh sampel sebanyak 95 responden. Instrumen yang digunakan adalah Zung Self-rating Anxiety Scale (ZSAS) yang bertujuan untuk mencatat adanya kecemasan dan menilai kuantitas tingkat kecemasan pada remaja. Metode pengumpulan data dengan menggunakan kuesioner melalui link google form yang disebar kepada responden. Data hasil penelitian dianalisis secara univariat yang disajikan secara distribusi frekuensi.

HASIL DAN PEMBAHASAN

Tabel 5.1 Distribusi responden berdasakan kelompok usia (n=95)

\begin{tabular}{ccc}
\hline \multirow{2}{*}{ Usia (tahun) } & \multicolumn{2}{c}{ Frekuensi } \\
\cline { 2 - 3 } & Jumlah & Presentase (\%) \\
\hline $11-13$ & 7 & $7,4 \%$ \\
\hline $14-16$ & 10 & $10,5 \%$ \\
\hline
\end{tabular}

\begin{tabular}{|c|c|c|}
\hline $17-20$ & 78 & $82,1 \%$ \\
\hline Total & 95 & $100 \%$ \\
\hline
\end{tabular}
dari sebagian besar responden berada pada umur 17-20 tahun yaitu sebanyak 78 responden. Mayoritas responden berada pada masa remaja lanjut (Late adolescence).

Tabel 5.2 Distribusi responden berdasakan tingkat pendidikan $(\mathbf{n}=95)$

\begin{tabular}{|c|c|c|}
\hline \multirow{2}{*}{$\begin{array}{l}\text { Tingkat } \\
\text { Pendidikan }\end{array}$} & \multicolumn{2}{|c|}{ Frekuensi } \\
\hline & Jumlah & Presentase (\%) \\
\hline Pendidikan Dasar & 5 & $5,3 \%$ \\
\hline Pendidikan & & \\
\hline Menengah & & \\
\hline Pertama & 7 & $7,4 \%$ \\
\hline Pendidikan & & \\
\hline Menengah Atas & 29 & $30,5 \%$ \\
\hline Pendidikan Tinggi & 54 & $56,8 \%$ \\
\hline Total & 95 & $100 \%$ \\
\hline
\end{tabular}

Tabel 5.3 Distribusi responden berdasakan tingkat kecemasan remaja $(\mathbf{n}=95)$

\begin{tabular}{lcc}
\hline \multirow{2}{*}{ Kategori } & \multicolumn{2}{c}{ Frekuensi } \\
\cline { 2 - 3 } & Jumlah & Presentase \\
\hline Kecemasan Ringan & 76 & $80,0 \%$ \\
\hline Kecemasan Sedang & 8 & $8,4 \%$ \\
\hline Kecemasan Berat & 10 & $10,5 \%$ \\
\hline Kecemasan Panik & 1 & $1,1 \%$ \\
\hline Total & $\mathbf{9 5}$ & $\mathbf{1 0 0 \%}$ \\
\hline
\end{tabular}

Tabel 5.3 menunjukkan bahwa responden terbanyak merupakan remaja dengan tingkat kecemasan ringan yaitu sebesar $80,0 \%$.

\begin{tabular}{l} 
Tabel 5.4 Distribusi responden berdasakan \\
$\begin{array}{c}\text { Kebiasaan Baru di Masa Pandemi COVID- } \\
19(\mathbf{n}=95)\end{array}$ \\
$\begin{array}{c}\text { Jenis } \\
\begin{array}{c}\text { Kebiasaan } \\
\text { Baru }\end{array}\end{array}$ \\
\cline { 2 - 2 }
\end{tabular}

\begin{tabular}{llll}
\hline Cuci Tangan & Tidak & & \\
Menggunakan & Pernah & 0 & $0,0 \%$ \\
\cline { 2 - 4 } $\begin{array}{l}\text { Sabun/ } \\
\text { Menggunakan }\end{array}$ & Kadang- & & \\
Handsanitazer & Sering & 15 & $15,8 \%$ \\
\hline
\end{tabular}

[Author : Irma Maya Puspita, Annisa’ Wigati Rosifa, A’im Matun Nadhiroh] | Publish : 29 Januari 2021 | Vol.5, No.1, Tahun 2021 | 


\begin{tabular}{|c|c|c|c|}
\hline & Selalu & 58 & $61,1 \%$ \\
\hline Total & & 95 & $100 \%$ \\
\hline \multirow{6}{*}{$\begin{array}{l}\text { Penggunaan } \\
\text { Masker } \\
\text { dengan Benar } \\
\text { di Area Publik }\end{array}$} & Tidak & & \\
\hline & Pernah & 0 & $0,0 \%$ \\
\hline & Kadang- & & \\
\hline & kadang & 3 & $3,2 \%$ \\
\hline & Sering & 10 & $10,5 \%$ \\
\hline & Selalu & 82 & $86,3 \%$ \\
\hline Total & & 95 & $100 \%$ \\
\hline \multirow{6}{*}{$\begin{array}{l}\text { Jaga Jarak } \\
\text { Minimal } 1 \\
\text { Meter }\end{array}$} & Tidak & & \\
\hline & Pernah & 0 & $0,0 \%$ \\
\hline & Kadang- & & \\
\hline & kadang & 15 & $15,8 \%$ \\
\hline & Sering & 32 & $33,7 \%$ \\
\hline & Selalu & 48 & $50,5 \%$ \\
\hline Total & & 95 & $100 \%$ \\
\hline \multirow{5}{*}{$\begin{array}{l}\text { Stay At } \\
\text { Home/ Di } \\
\text { Rumah Saja }\end{array}$} & Tidak & & \\
\hline & Pernah & 2 & $2,1 \%$ \\
\hline & $\begin{array}{l}\text { Kadang- } \\
\text { kadang }\end{array}$ & 13 & $13.7 \%$ \\
\hline & Sering & 27 & $28,4 \%$ \\
\hline & Selalu & 53 & $55,8 \%$ \\
\hline Total & & 95 & $100 \%$ \\
\hline \multirow{6}{*}{$\begin{array}{l}\text { Update } \\
\text { Informasi } \\
\text { terkait } \\
\text { COVID-19 }\end{array}$} & Tidak & & \\
\hline & Pernah & 3 & $3,2 \%$ \\
\hline & Kadang- & & \\
\hline & kadang & 32 & $33,7 \%$ \\
\hline & Sering & 31 & $32,6 \%$ \\
\hline & Selalu & 29 & $30,5 \%$ \\
\hline Total & & 95 & $100 \%$ \\
\hline
\end{tabular}

Berdasarkan tabel di atas, diketahui bahwa responden paling banyak yaitu sebesar $61,1 \%$ responden selalu mencuci tangan menggunakan sabun/ menggunakan handsanitazer setelah menyentuh benda diluar rumah (seperti: uang, gagang pintu dll). Berdasarkan tabel tersebut dapat dilihat juga bahwa paling banyak responden selalu menggunakan masker dengan benar di area publik yaitu sebesar 86,3\%. Sebagian besar responden (sebanyak 50,5\%) selalu menjaga jarak dari orang lain. Sebanyak $55,8 \%$ responden selalu menerapkan Stay At Home/ Di Rumah Saja

Selain itu, pada tabel menunjukkan distribusi responden berdasarkan kebiasaan remaja dalam mengupdate informasi terkait COVID-19. Berdasarkan tabel di atas, diketahui responden terbanyak yaitu sebesar $33,7 \%$ kadang-kadang mengupdate informasi terkait COVID-19.

\section{Gambaran Kecemasan Remaja Putri di Masa Pandemi COVID-19}

COVID-19 berpengaruh besar hampir di seluruh negara di dunia. Ketidakpastian tentang risiko kesehatan serta peningkatan kerugian finansial menyebabkan tekanan emosional dan peningkatan risiko gangguan kejiwaan. Gangguan pasca trauma, kecemasan, dan depresi diperkirakan terjadi selama dan setelah pandemi. Beberapa kelompok usia, seperti anak-anak dan remaja lebih rentan terhadap kesehatan mental [15].

Kecemasan merupakan gangguan mental yang saat ini umum terjadi pada remaja. Kecemasan merupakan perasaan yang samar tentang ketakutan terhadap apa yang akan terjadi. Pada umumnya, kecemasan disertai dengan perasaan ketidakpastian, ketidakberdayaan (helplessness), isolasi, perasaan terkucilkan dan perasaan tidak aman [16].

Kecemasan dapat menyebabkan gangguan fisik dan mental yang parah. Masa remaja adalah masa eksplorasi dan untuk pengembangan diri. Masa remaja adalah periode transisi kritis dari masa anak-anak ke masa dewasa [17]. Diperkirakan hampir 1 dari 3 remaja usia 13 sampai 18 tahun mengalami gangguan kecemasan. Kecemasan yang tidak terdiagnosis dan tidak diobati dapat mengganggu perkembangan psikologis normal dan menyebabkan beban yang signifikan pada kualitas hidup dan kesejahteraan individu [18]. Disamping itu, kecemasan dalam kategori tertentu dapat bermanfaat karena mampu membuat masyarakat lebih waspada, sehingga seseorang dapat melakukan pertahanan diri (self defence). [19].

Perempuan dengan gangguan kecemasan melaporkan keparahan gejala yang lebih tinggi dibandingkan dengan laki-laki. Remaja perempuan beresiko dua kali lebih mengalami kecemasan seperti: gangguan panik, GAD, dan PTSD, dan sekitar 1,5 kali beresiko OCD dan SAD. Beberapa penelitian menunjukkan bahwa faktor genetik dan hormon reproduksi 
wanita berperan peran penting dalam ekspresi perbedaan gender tersebut [20].

Selain itu, suatu penelitian menjelaskan bahwa perempuan lebih banyak mengalami depresi dibandingkan laki-laki. Hal ini disebabkan karena perempuan kurang asertif dan cenderung memiliki skor yang lebih rendah dalam kepemimpinan daripada laki-laki. Remaja perempuan lebih sering menggunakan coping ruminatif yaitu lebih memusatkan perhatiannya pada simptom-simptom depresi yang dialaminya, sedangkan remaja laki-laki cenderung mengalihkannya pada beberapa aktivitas fisik seperti menonton televisi, berperilaku agresif. Disamping itu, remaja perempuan kurang dominan, kurang agresif baik secara fisik maupun verbal dalam berinteraksi dengan kelompoknya [20].

Pada penelitian ini diperoleh bahwa tingkat kecemasan remaja berada pada kategori ringan. Kecemasan ringan merupakan ketegangan yang dialami sehari-hari. Kecemasan pada level ini diperlukan oleh individu agar dapat mengatasi suatu kejadian dengan baik yang dalam hal ini yaitu pandemi Covid - 19. Kecemasan ini penting karena mampu memotivasi seseorang, dapat meningkatkan kesadaran individu, serta mempertajam perasaan sehingga dianggap penting dan konstruktif [16].

Respons dari kecemasan ringan terdiri dari respons fisik, kognitif, dan emosional. Respons fisik yang terjadi yaitu : sedikit gelisah, penuh dengan perhatian, ketegangan otot ringan, sadar terhadap lingkungan, rileks, dan rajin. Kecemasan ringan memiliki respons kognitif yaitu : terlihat tenang, percaya diri, waspada, memiliki persepsi yang luas, sedikit perasaan gagal, perhatian terhadap banyak hal, mempertimbangkan informasi, dan mampu belajar secara optimal. Selain itu, respons emosional yang terjadi yaitu : suka menyendiri, terstimulasi, dan tenang [16].

Kecemasan yang disebabkan virus corona dipengaruhi beberapa faktor, yaitu minimnya pengetahuan terkait COVID-19, kurangnya penerapan perilaku hidup bersih dan sehat, ketidaksiapan terhadap perubahan yang terjadi tiba-tiba dan berpengaruh besar, minimalnya pengetahuan tentang kesehatan fisik dan psikologis, serta kurangnya koping psikologis [21].

Koping psikologis terhadap COVID-19 perlu diperhatikan yang bertujuan untuk mencegah terjadinya stress yang berkepanjangan sehingga memicu terjadinya trauma terhadap kejadian COVID-19. Apabila kondisi tersebut tidak segera diatasi, maka beresiko meningkatkan depresi. Hal ini dapat memicu tindakan berbahaya seperti resiko bunuh diri [22].

Beberapa solusi yang disarankan kepada masyarakat dalam mengatasi kecemasan selama masa pandemi, yaitu mengakses informasi secara tepat, benar, dan berasal dari sumber yang terpercaya; berpikir positif; melakukan aktivitas menyenangkan, dan olahraga [23].

\section{Kepatuhan Remaja Putri terhadap Kebiasaan Baru di Masa Pandemi COVID-19}

COVID-19 berdampak terhadap berbagai aspek kehidupan masyarakat di seluruh dunia yang mencakup aspek ekonomi, kesehatan, pendidikan, sosial, budaya dan lain-lain. Kebijakan yang telah dibuat oleh pemerintah dalam menghadapi pandemi COVID-19 seperti kebijakan tinggal di rumah; menggunakan masker; melakukan cuci tangan; Pembatasan Sosial Berskala Besar (PSBB); dan pemberlakuan kebijakan New Normal [24].

Tatanan normal baru perlu diterapkan karena masih belum ditemukannya vaksin sebagai antiviral spesifik untuk mengatasi COVID-19 [25]. Peran masyarakat, termasuk remaja dalam tatanan normal baru sangat dibutuhkan untuk mencegah terjadinya penularan yang lebih banyak. Pada penelitian Faura (2020) menjelaskan sebagian besar responden $(95,4 \%)$ berpendapat perlu adanya penerapan protokol kesehatan selama masa pandemi. Disamping itu, sebesar $87,7 \%$ responden mengetahui jenis protokol kesehatan [26].

COVID-19 telah menginfeksi masyarakat di seluruh dunia pada waktu yang relatif singkat. Hal tersebut diperparah dengan adanya orang tanpa gejala dan dapat menyebar 
ke orang lain [27]. Oleh karena itu, pemerintah menghimbau kepada seluruh masyarakat untuk melindungi diri. Hal ini bertujuan untuk mengantisipasi adanya peningkatan penyebaran dan jumlah infeksi.

\section{Cuci Tangan/ Menggunakan Handsanitizer}

Cuci tangan adalah salah satu cara yang efektif untuk membunuh kuman. Virus COVID19 dapat menempel pada bagian tubuh terutama tangan yang menyentuh benda yang sudah tertular oleh droplet. Menurut Kementerian Kesehatan, sebesar $75 \%$ penularan virus Covid melalui percikan air ludah pada benda [28].

Pada penelitian ini, sebanyak 58 responden $61,1 \%$ ) menyatakan selalu mencuci tangan menggunakan sabun/ menggunakan handsanitazer setelah menyentuh benda diluar rumah (seperti: uang, gagang pintu dll). Hal ini sesuai dengan penelitian Ika dan Anisa (2020) yang diperoleh bahwa sebagian responden sudah melakukan cuci tangan setelah menyentuh benda benda, tetapi hanya sebagian yang mencuci tangan sesuai protokol WHO [29]. Selain itu, penelitian lain menunjukkan terdapat 50,46\% kepatuhan cuci tangan dengan sabun [30]. Faktor yang berpengaruh terhadap tingkat kepatuhan cuci tangan adalah faktor usia [31].

\section{Penggunakan masker dengan benar di area publik}

Selain mencuci tangan dan menggunakan handsanitizer, pengetahuan terkait pemakaian masker dapat menghambat penyebaran virus. Tingkat pengetahuan masyarakat mempengaruhi kepatuhan menggunakan masker sebagai upaya pencegahan penyebaran virus corona [32].

Pada penelitian ini, sebanyak 82 responden $(86,3 \%)$ selalu menggunakan masker dengan benar di area publik. Hal tersebut sesuai dengan penelitian Ika dan Anisa (2020) yang sebagian besar responden yaitu sebanyak $72,2 \%$ sudah mematuhi penggunaan masker [29].

Masker yang mempunyai efektifitas yang baik terhadap pencegahan COVID-19 adalah masker bedah. Tingkat perlindungan masker bedah yaitu sebesar $56 \%$ dari partikel dengan ukuran nanometer. Namun, masyarakat masih dapat menggunakan masker kain sebagai upaya pencegahan penularan covid- 19 melalui percikan air ludah/droplet [33].

\section{Jaga Jarak dari Orang Lain Minimal 1 Meter}

Pada penelitian ini, sebanyak 48 responden $(50,5 \%)$ selalu menjaga jarak minimal 1 meter. Hal tersebut sesuai dengan penelitian oleh Yanti, dkk (2020) yang menjelaskan bahwa $93 \%$ responden mempunyai perilaku yang baik terhadap upaya pencegahan COVID-19 di Indonesia dengan social distancing [34]. Penerapan kebijakan social distancing yaitu beraktivitas dari rumah; menghindari keramaian dan membatasi kegiatan di fasilitas umum [35].

\section{Stay At Home / Di Rumah Saja}

Pada penelitian ini, mayoritas responden yaitu sebanyak 53 responden $(55,8 \%)$ selalu menerapkan Stay At Home / Di Rumah Saja. Pemerintah juga menekankan perlunya tinggal di rumah (stay at home) bagi seluruh WNI. Pemberitahuan Stay at Home yang lebih ketat dapat mengurangi berkumpulnya massa di depan umum juga. Tinjauan sistematis terhadap 45 penelitian menunjukkan bahwa infeksi saluran pernapasan akut adalah penyakit yang paling umum menyebar melalui pertemuan massal, termasuk festival dan acara keagamaan [36].

Disamping itu, pembatasan temu masal dan penutupan sekolah menyebabkan siswa lebih banyak tinggal di rumah (Stay At Home) dan tidak beraktifitas seperti biasanya, Hal ini dapat menyebabkan psikologis seseorang akan merasa lelah dan jenuh dengan keadaan. Studi sebelumnya menjelaskan bahwa diadakannya pembatasan rapat massal dan penutupan sekolah berdampak pada kesehatan masyarakat selama pandemi [37].

\section{Update Informasi terkait COVID-19}

Pada penelitian ini, diketahui sebanyak 32 responden yaitu sebesar $33,7 \%$ dalam poin mengupdate informasi terkait COVID-19 tergolong dalam kategori kadang-kadang. Pengetahuan yang baik dapat didukung oleh 
penerimaan terhadap informasi yang beredar di masyarakat tentang COVID-19 [38].

Seseorang yang telah mengetahui tentang suatu informasi tertentu, maka dia akan mampu menentukan dan mengambil keputusan bagaimana dia harus menghadapinya. Dengan kata lain, saat seseorang mempunyai informasi tentang COVID-19, maka ia akan mampu untuk menentukan bagaimana dirinya harus berperilaku terhadap COVID-19 tersebut [39].

Berdasarkan hasil survey, pengetahuan masyarakat yang masih perlu ditingkatkan antara lain tentang pemeriksaan deteksi dini dengan Rapid Diagnostic Test yang masih dianggap sebagai tes penentu COVID-19 dan beberapa responden yang menganggap alasan penggunaan masker dikarenakan virus corona dapat terbang bebas di udara [40].

Beberapa hal yang perlu diperhatikan dalam menerima pemberitaan COVID-19, yaitu mencari informasi yang benar, menyaring informasi sebelum menyebarkan. Metode sharing melalui WA, Facebook, dan Instagram terbukti secara efektif dapat meningkatkan pemahaman terkait New Normal dan penerapan protokol kesehatan pada remaja. Sosialisasi dan edukasi yang baik oleh pemerintah sangat diperlukan untuk memperbaiki persepsi masyarakat yang masih kurang tepat. Oleh karena itu, hal tersebut merupakan kunci utama keberhasilan penanganan pandemik COVID-19 [41].

\section{KESIMPULAN}

Hasil penelitian diketahui bahwa tingkat kecemasan remaja pada masa pandemi COVID19 dalam kategori ringan. Remaja dengan kecemasan ringan masih dapat melakukan aktivitas seperti biasa, dan dapat mengatasi hal tersebut dengan baik. Oleh karena itu, berdasarkan data yang diperoleh, sebagian besar remaja dapat melakukan protokol kesehatan dengan baik.

Kecemasan yang dialami remaja dapat menjadikannya lebih waspada (aware) terhadap bahaya ancaman COVID-19. Kecemasan yang dikelola dengan baik mencegah terjadinya kepanikan yang berlebihan. Menyeleksi informasi yang diterima merupakan kunci dalam mengelola kecemasan selama masa pandemi
COVID-19.

Selain itu, dalam meminimalisir kecemasan (anxiety) pada remaja perlu peran orangtua dengan mendampingi, memotivasi, memberikan pengetahuan tentang COVID-19 ini. Pelayanan yang dapat diberikan kepada remaja untuk menurunkan tingkat kecemasan selama masa pandemi COVID-19 melalui konseling individu, bimbingan, dan konseling kelompok.

\section{DAFTAR PUSTAKA}

[1] Pratiwi, A. D., "Gambaran Penggunaan Masker di Masa Pandemi COVID-19 pada Masyarakat di Kabupaten Muna”, Prosiding Seminar Nasional Problematika Sosial Pandemi COVID19, pp. 52-57, Mei 20, 2020.

[2] Kemkes RI, "Pertanyaan dan Jawaban terkait COVID-19 Kementrian Kesehatan.” 04 Maret 2020, [Online]. Tersedia: https://www.kemkes.go.id/article/view/2 0030400008/FAQ-Coronavirus.html [Diakses : 05 September 2020].

[3] Banerjee, D., "The COVID-19 outbreak : Crucial role the psychiatrists can play". Asian J. Psychiat, Vol. 50 (102014), Mar. 2020.

[4] Brooks, S.K., Webster, R.K., Smith, L.E., Woodland, L., Wessely, S., Greenberg, N., \& Rubin, G.J., "The Psychological Impact Of Quarantine And How To Reduce It: Rapid Review Of The Evidence", The Lancet, Vol. 395, Issue 10227, P. 912-920, Feb. 2020.

[5] Nadhira, A. M., "Menjaga Kesehatan Mental saat Pandemi Virus Corona." 27 Mei 2020, [Online]. Tersedia https://www.alodokter.com/menjagakesehatan-mental-saat-pandemi-viruscorona [Diakses : 07 September 2020].

[6] Sabir, A., \& Phil, M., "Gambaran Umum persepsi masyarakat terhadap bencana di Indonesia", Jurnal Ilmu Ekonomi dan Sosial, Vol.5, No.3, pp. 304-326, 2016.

[7] Irawati, T., "Menuju Adaptasi Kebiasaan Baru." 19 Juni 2020, [Online]. Tersedia : http://promkes.kemkes.go.id/menujuadaptasi-kebiasaan-baru [Diakses : 15 
Sepember 2020].

[8] Tjukup, I. K., Putra, I. P. R. A., Yustiawan, D. G. P., \& Usfunan, J.Z., "Penguatan Karakter Sebagai Upaya Penanggulangan Kenakalan Remaja (Juvenile Delinquency)", KERTHA WICAKSANA: Sarana Komunikasi Dosen dan Mahasiswa, 14 (1), 29-38, 2020.

[9] Dani, J. A., \& Mediantara, Y., "COVID19 dan Perubahan Komunikasi Sosial", Persepsi: Communication Journal, Vol. 3, No.1, pp. 94-102, 2020.

[10] Rochmawati, I., "Mengelola Cemas pada Masa Pandemi COVID-19." 16 April 2020, [Online]. Tersedia : https://manajemencovid.net/2020/04/16/re portase-webinar-mengelola-kecemasanpada-remaja-selama-masa-pandemiCOVID-19-rabu-15-april-2020-pukul-1300-15-00/ [Diakses : 07 September 2020].

[11] WHO, “Coping with Stress", 01 Juli 2020, [Online]. Tersedia

https://www.cdc.gov/coronavirus/2019ncov/daily-life-coping/managing-stressanxiety.html [Diakses pada tanggal 5 September 2020].

[12] Fitria, L., Ifdil, "Kecemasan Remaja pada Masa Pandemi COVID-19", Jurnal Educatio (Jurnal Pendidikan Indonesia), Vol.6, No.1, pp. 1-4, Jul. 2020.

[13] Sari, D. A., Sholihah, N., Atiqoh, "Hubungan antara Pengetahuan Masyarakat dengan Kepatuhan Penggunaan Masker sebagai Upaya Pencegahan Penyakit COVID-19 di Ngronggah", Jurnal Ilmiah Rekam Medis dan Informatika Kesehatan, Vol. 10, No.1, pp. 52-55, Feb.2020.

[14] Syadidurrahmah, F. et al, "Perilaku Physical Distancing Mahasiswa UIN Syarif Hidayatullah Jakarta pada Masa Pandemi COVID-19", Indonesian Journal of Health Promotion and Behaviour, Vol. 02, No. 1, pp. 29-37, Jun. 2020.

[15] De Miranda, D. M., Da Silva Athanasio, B., De Sena Oliveira, A. C., \& Silva, A. C. S. "How is COVID-19 pandemic impacting mental health of children and adolescents?". International Journal of Disaster Risk Reduction.2020. p.101845.
[16] Stuart, \& Sundeen, "Keperawatan Psikitrik: Buku Saku Keperawatan Jiwa Edisi 5". Jakarta: EGC. (2015).

[17] Garcia, I., \& O'Neil, J., "Anxiety in Adolescents". The Journal for Nurse Practitioners. 2020.

[18] McCarthy C. "Anxiety in teens is rising: what's going on?"2019. [Online]. Tersedia:

https://www.healthychildren.org/English /health-issues/conditions/emotionalproblems/Pages/Anxiety-Disorders.aspx. [Diakses : 15 September 2020]

[19] ActionAid, International Federation of the Red Cross and Red Crescent Societies (IFRC), dkk, "Kesepakatan untuk Anak Muda dalam Aksi Kemanusiaan COVID-19: Bekerja dengan dan untuk anak muda". Mei 2020.

[20] Kinrys, G, \& Wygant, L. "Anxiety disorders in women: does gender matter to treatment?". Rev Bras Psiquiatr. 2015.

[21] Zhang, Jun, Weili Wu, Xin Zhao, and Wei Zhang. "Recommended Psychological Crisis Intervention Response to the 2019 Novel Coronavirus Pneumonia Outbreak in China: A Model of West China Hospital." Precision Clinical Medicine 3. 2020.

[22] Holmes, Emily A., et al. "Multidisciplinary research priorities for the COVID-19 pandemic: a call for action for mental health science." The Lancet Psychiatry. 2020.

[23] Rinaldi, R.A., Yuniasanti, R., "Kecemasan pada Masyarakat saat Masa Pandemi Covid - 19 di Indonesia". Covid - 19 dalam Ragam Tinjauan Perspektif. MBridge Press. pp. 137-150. 2020.

[24] Gugus Tugas Percepatan COVID-19., "Protokol Percepatan Penanganan Pandemi COVID-19 (Corona Virus Disease 2019)", 13 Mei 2020, [Online]. Tersedia:

https://covid19.go.id/p/protokol/protokol -percepatan-penanganan-pandemiCOVID-19-corona-virus-disease-2019.

[25] Gennaro, F. et al., "Coronavirus 
Diseases (COVID-19) Current Status and Future Perspectives : A Narrative Review", International Journal of Environmental Research and Public Health, 17, 2-11. 2020.

[26] Pinasti, F. D. A., "Analisis Dampak Pandemi Corona Virus Terhadap Tingkat Kesadaran Masyarakat dalam Penerapan Protokol Kesehatan", Wellness and Healthy Magazine. Vol. 2, Issue 2, p. 237 - 249, Agustus. 2020.

[27] Kumar, M., \& Dwivedi, S., "Impact of Coronavirus Imposed Lockdown on Indian Population and their Habits". International Journal of Science and Healthcare Research, Vol.5, Issue: 2, pp. 88-97, Juni. 2020.

[28] Kementerian kesehatan RI. "Cuci Tangan Kunci Bunuh Virus COVID-19", 7 Mei 2020, [Online]. Tersedia: https://www.kemkes.go.id/article/view/20 050700001/cuci-tangan-kuncibunuhvirus-COVID-19.html. 2020 [Diakses: 16 September 2020].

[29] Purnamasari, I \& Raharyani, A. E., "Tingkat Pengetahuan dan Perilaku Masyarakat Kabupaten Wonosobo tentang COVID-19", Jurnal Ilmiah Kesehatan. 2020.

[30] Demsa, S., "Kepatuhan Civitas Akademik Poltekkes Kemenkes Bengkulu Mengikuti Peraturan Pemerintah Dalam Pencegahan penularan Virus COVID-19", [Online]. Tersedia:

http://sinta.ristekbrin.go.id/covid/penelitia n [Diakses: 16 September 2020].

[31] Ta'adi. Setyorini, Erni. Amalya, Rifqi., "Faktor yang Berhubungan dengan Kepatuhan Cuci Tangan 6 Langkah Momen Pertama pada Keluarga Pasien di Ruang Anak", Jurnal Ners dan Kebidanan, Vol. 6, No. 2, pp.203-210, Agustus. 2019.

[32] Sari, D.P. dan 'Atiqoh N.S. "Hubungan Antara Pengetahuan Masyarakat dengan Kepatuhan Penggunaan Masker Sebagai Upaya Pencegahan Penyakit COVID-19 di Ngronggah", Jurnal Ilmiah Rekam Medis dan Informatika Kesehatan, Vol 10, No 1, Februari. 2020.
[33] Ika. "Efektifitas Masker Kain Cegah COVID-19". 14 April 2020, [Online]. Tersedia

https://ugm.ac.id/id/newsPdf/19280efektivitas-masker-kain-cegah-COVID19-paling-rendah. [Diakses: 16 September 2020].

[34] Yanti, B., et al., "Community Knowledge, Attitudes, and Behavior Towards Social Distancing Policy As Prevention Transmission of COVID-19 in Indonesia", Jurnal Administrasi Kesehatan Indonesia, Vol. 8, No.1, pp. 4-14. 2020.

[35] World Health Organization., "Coronavirus Disease (COVID-19) Situation Report". World Health Organization. Januari 2020, [Online]. Tersedia:

https://www.who.int/emergencies/diseas es/novel-coronavirus-2019/situationreports. [Diakses: 16 September 2020].

[36] Suppawittaya, P., Yiemphat, P., \& Yasri, P., "Effects of Social Distancing, SelfQuarantine and Self-Isolation during the COVID-19 Pandemic on People's Well Being, and How to Cope with It", International Journal of Science and Healthcare Research, 5(June), 12-20. 2020.

[37] Karami M, Doosti-Irani A, Ardalan A, et al., "Public health threats in mass gatherings: A systematic review", Disaster Med Public Health Prep. 13 (56):1035- 46. 2019.

[38] Juni, P., et. al., "Impact of climate and public health interventions on the COVID-19 pandemic: A prospective cohort study". Cmaj, Vol. 192. Mei. 2020.

[39] Sulistyaningtyas, T., "Informasi Wabah Virus COVID-19: Kuasa Pengetahuan dan Kelas Sosial", [Online]. Tersedia: https://sinta.ristekbrin.go.id/covid/penelit ian [Diakses : 17 September 2020].

[40] Ahmadi, Kesehatan Masyarakat, teori dan aplikasi. Jakarta: Raja Grafindo. 2013.

[41] Olum .R, Chekwech .G, et al., "Coronavirus Disease-2019: Knowledge, 
Attitude, and Practices of Health Care Workers at Makerere University Teaching Hospitals, Uganda, Original Research Article, Front". Public Health, 30 April 2020 , [Online]. Tersedia; https://doi.org/10.3389/fpubh.2020.00181[ Diakses: 17 September 2020].

[42] Aulia, K. N., "Meningkatkan Kesadaran Masyarakat untuk Memperhatikan Prokes (Protokol Kesehatan) dalam Beraktivitas di Era NeNo (New Normal) dengan Media PEPC (Poster Edukasi Pencegahan COVID-19) Melalui Media Wafagram (WA, Facebook, dan Instagram) di Kampung Padang Laban, Nagari Pasia Pelangai, Kecamatan Ranah Pesisir, Kabupaten Pesisir Selatan". 31 Juli 2020, [Online]. Tersedia : https://osf.io/3upaj [Diakses 15 September 2020]. 